\title{
Determination of the Taxonomic Status of Tomato Crown and Root Rot Isolates in Fusarium oxysporum by DNA Homology*
}

\author{
Shiro KuninaGA** and Ryozo YoKosaWA**
}

\begin{abstract}
The taxonomic status of Japanese tomato crown and root rot isolates ascribed to Fusarium oxysporum $\mathrm{f}$. sp. lycopersici race $\mathrm{J} 3$ was determined on the basis of DNA-DNA reassociation kinetics. As compared with DNA homology among races of forma specialis lycopersici, isolates of race $\mathrm{J} 3$ showed relatively low homology (74-88\%) with isolates of other races which caused typical vascular wilts of tomato, and shared high DNA homology $(96-99 \%)$ within the race. By contrast, isolates of race J3 showed high DNA homology (95-100\%) with an isolate of F. oxysporum f. sp. radicis-lycopersici, but exhibited low homology $(69-87 \%)$ with isolates of other formae speciales of $F$. oxysporum. These results suggest that the causal fungi of tomato crown and root rot in Japan, previously proposed as race $\mathrm{J} 3$ of forma specialis lycopersici, should be designated as a different forma specialis: F. oxysporum f. sp. radicis-lycopersici (Jarvis and Shoemaker, 1978).
\end{abstract}

(Received May 7, 1990)

Key words: tomato crown and root rot disease, Fusarium oxysporum, Fusarium oxysporum f. sp. radicis-lycopersici, molecular taxonomy, DNA relatedness.

\section{INTRODUCTION}

A crown and root rot of tomatoes caused by Fusarium oxysporum Schlecht. was first discovered in southern Japan in 1967 ${ }^{38}$. Since then the disease has become a serious problem in the greenhouse tomato production, having been reported from numerous tomato-growing areas in $\mathrm{Japan}^{16,17,32)}$. An identical disease also has been reported from U.S.A. ${ }^{22,27,30,31,35)}$, Canada $^{13)}$, Greece ${ }^{24)}$, Israel ${ }^{18)}$ and Europe ${ }^{6)}$.

The designation for subspecific taxon of tomato crown and root rot isolates has not been used uniformly throughout the literature. Japanese researchers ${ }^{32,38)}$ designated a new race, $\mathrm{J} 3$, of $F$. oxysporum f. sp. lycopersici, based on its pathogenicity to the tomato differential variety Walter which is resistant to races $\mathbf{J} 1$ and $\mathbf{J} 2$ so far known in Japan. Races $\mathbf{J} 1$ and $\mathbf{J} 2$ are equivalent to races 1 and 2, respectively of U.S. and European workers, or to races 0 and 1 in the nomenclature proposed by Gabe ${ }^{10)}$. On the other hand, Jarvis and Shoemaker ${ }^{14)}$ have proposed a new forma specialis radicis-lycopersici for the fungus, because the disease symptoms it causes are clearly distinct from those caused by $F$. oxysporum f. sp. lycopersici.

Recently, a new Fusarium disease with typical vascular wilt symptoms on tomato cultivars resistant to race 2 has been reported from Australia and U.S.A., and a third race of $F$. oxysporum f. sp. lycopersici was assigned to the causal agent ${ }^{11,37)}$. As a result, confusion has arisen in the

* This work was supported in part by Research Grant No. 1560056 from the Ministry of Education, Science and Culture of Japan.

** Department of General Education, Higashi Nippon Gakuen University, Ishikari-Tohbetsu, Hokkaido 061-02, Japan＼cjkstart東日本学園大学教養部 
subspecific classification of tomato crown and root rot isolates as race series of forma specialis lycopersici.

New methods in molecular biology now make possible the assessment of the subspecific classification in $F$. oxysporum at the molecular level ${ }^{8,15,25)}$. In a previous study ${ }^{20)}$, we suggested that the reassociation analysis of DNA may be useful in studies involving classification of formae speciales in F. oxysporum.

The purpose of this study was to determine genetical relatedness among races of forma specialis lycopersici and forma specialis radicis-lycopersici of $F$. oxysporum on the basis of DNA-DNA reassociation kinetics, as well as to elucidate the taxonomic status for the causal organism of tomato crown and root rot disease in Japan. A partial account of this work has previously been reported ${ }^{21)}$.

\section{MATERIALS AND METHODS}

Fungal strain. Twenty-two isolates of $F$. oxysporum f. sp. lycopersici and nine isolates from other formae speciales of this species used in this study are listed in Table 1. The assignment of Japanese races (race $\mathbf{J} 1, \mathbf{J} 2$ and $\mathbf{J} 3$ ) of forma specialis lycopersici was made on the basis of Japanese differential system by the researchers who supplied the isolates. All isolates of race $\mathrm{J} 3$ used were collected from crown and root rot-affected tomato plants. The isolates of U.S.A. races (race 1, 2 and 3) of forma specialis lycopersici were provided from Dr. Jones, University of Florida. The isolate (CC\#85) of forma specialis radicis-lycopersici was supplied by Dr. Jarvis, Agriculture Canada Research Station, Harrow. All isolates were grown in potato dextrose broth for 7 or 8 days at $28^{\circ} \mathrm{C}$. The mycelia of each isolate were washed with distilled water, then filtered through a filter paper, frozen, and lyophilized.

Isolation of DNA. Extraction of fungal DNA was carried out according to a modified method $^{19)}$ of Britten et al. ${ }^{7)}$ DNA purity was tested on the basis of absorbance ratio and DNA hyperchromicity. Analysis in $\mathrm{CsCl} /$ bisbenzimide density gradient centrifugation showed each DNA to contain less than $3.4 \%$ mitochondrial DNA.

DNA-DNA reassociation kinetics. The extent of DNA reassociation was determined spectrophotometrically, essentially based on the method reported by Seidler and Mandel ${ }^{33)}$ and Seidler et al. ${ }^{34)}$, as described previously ${ }^{19}$. DNA samples were sheared on ice by sonic treatment (Bronson Sonifier, Model B-12). Sheared DNA fragments had a molecular weight of approximately $5.5 \times 10^{5}$ daltons. Sheared DNA samples $(75-85 \mu \mathrm{g} / \mathrm{ml})$ were dissolved in $5 \times$ SSC (SSC: $150 \mathrm{mM} \mathrm{NaCl}, 15 \mathrm{mM}$ sodium citrate, $\mathrm{pH} 7.0$ ) containing $20 \%$ dimethylsulfoxide to promote reassociation. To determine relative homology of DNA unique sequences, a major portion of repetitive sequences was removed from the total DNA sample according to the technique described previously ${ }^{20)}$. DNA homology values were calculated using equation proposed by Seidler and Mandel ${ }^{33)}$.

\section{RESULTS}

\section{Genetic relatedness between races of $F$. oxysporum $f$. sp. lycopersici}

Percent homology values for hybridization reactions among races of forma specialis lycopersici are summarized in Table 2. All the isolates of race $\mathrm{J} 3$ showed relatively low homology values $(74.4 \%$ to $88.9 \%$ ) with isolates of other races (J1, J2, 1, 2 and 3). Isolates of Japanese races, $\mathbf{J} 1$ and $\mathbf{J} 2$, hybridized with isolates of American races, 1, 2 and 3 at consistently high rates (above $96.1 \%$ ).

Genetic relatedness between races of $F$. oxysporum $f$. sp. lycopersici and other formae speciales of $F$. oxysporum

DNA relatedness between races of forma specialis lycopersici and nine other formae speciales 
Table 1. List of isolates of Fusarium oxysporum used in this study

\begin{tabular}{|c|c|c|}
\hline \multicolumn{2}{|c|}{ Isolate } & \multirow[t]{2}{*}{ Source a) } \\
\hline \multicolumn{2}{|c|}{ f. sp. lycopersici } & \\
\hline \multirow[t]{3}{*}{ race $\mathrm{J1}$} & SUF 119 & Shinshu Univ. (T. Matuo) \\
\hline & Tomato V & Vegetable and Ornamental Crops Res. Sta. \\
\hline & Tomato $\mathrm{H}$ & Higashi Nippon Gakuen Univ. (S. Kuninaga) \\
\hline \multirow[t]{4}{*}{ race $\mathbf{J} 2$} & SUF 803 & Shinshu Univ. (T. Matuo) \\
\hline & IFO 31213 & IFO, Shizuoka Agr. Expt. Sta. (T. Suzui; F3-1) \\
\hline & F-1 & Kochi Pref. Inst. Agr. Fores. Sci. (T. Kobayashi) \\
\hline & F-8 & $\cdot$ \\
\hline \multirow[t]{9}{*}{ race $\mathbf{J} 3$} & FOly & Vegetable and Ornamental Crops Res. Sta. \\
\hline & Mie & National Agr. Res. Ctr. (H. Hagiwara) \\
\hline & KEF-2R1 & Kanagawa Horticultural Expt. Sta. (N. Kita) \\
\hline & KEF-2R4 & 11 \\
\hline & Y31 & "l \\
\hline & Y11a & $\prime \prime$ \\
\hline & h2 & $\prime \prime$ \\
\hline & $\mathrm{F} 212$ & Kochi Pref. Inst. Agr. Fores. Sci. (T. Kobayashi) \\
\hline & F213 & $\prime \prime$ \\
\hline \multirow[t]{2}{*}{ race 1} & AFL 626 & Univ. of Florida (J.P. Jones) \\
\hline & AFL 7388 & $\prime \prime$ \\
\hline \multirow[t]{2}{*}{ race 2} & AFL 548 & $\prime \prime$ \\
\hline & AFL 7399 & "l \\
\hline \multirow[t]{2}{*}{ race 3} & AFL 5397 & $\prime \prime$ \\
\hline & AFL 8174 & "l \\
\hline \multicolumn{3}{|c|}{ f. sp. radicis-lycopersici } \\
\hline & $\mathrm{CC} \# 85$ & Agr. Canada Res. Sta. (W.R. Jarvis) \\
\hline \multicolumn{3}{|c|}{ f. sp. melongenae } \\
\hline & IFO 9968 & IFO, Shinshu Univ. (T. Matuo) \\
\hline \multicolumn{3}{|c|}{ f. sp. nicotianae } \\
\hline & IFO 6386 & IFO, Tottori Univ. (M. Nishimura) \\
\hline \multicolumn{3}{|c|}{ f. sp. melonis } \\
\hline & F.O.-1 & Shizuoka Agr. Exp. St. \\
\hline \multicolumn{3}{|c|}{ f. sp. raphani } \\
\hline \multicolumn{3}{|c|}{ f. sp. phaseoli } \\
\hline & IFO 9970 & IFO, Shinshu Univ. (T. Matuo) \\
\hline \multicolumn{3}{|c|}{ f. sp. gladioli } \\
\hline \multicolumn{3}{|c|}{ f. sp. asparagi } \\
\hline & IFO 31382 & IFO, NIAES (T. Suzui) \\
\hline \multicolumn{3}{|c|}{ f. sp. spinaciae } \\
\hline
\end{tabular}

a) IFO : Institute for Fermentation, Osaka.

NIAES: National Institute of Agro-Environmental Sciences.

of this species was compared. As shown in Table 3, race J3 isolate (FOly) hybridized at perfect rates $(97.7-99.8 \%$ ) with isolate (CC\#85) of forma specialis radicis-lycopersici, but at low rates $(69.2-87.4 \%)$ with isolates of other formae speciales. Two isolates (SUF 119 and SUF 803) from race $\mathrm{J} 1$ and $\mathrm{J} 2$ showed a low relatedness $(68.1-88.2 \%)$ with isolates from forma specialis radicis-lycopersici and other formae speciales.

Genetic relatedness between race J3 of F. oxysporum $f$. sp. lycopersici and $F$. oxysporum f. sp. radicis-lycopersici

DNA relatedness between race $\mathrm{J} 3$ of forma specialis lycopersici and forma specialis radicis- 
Table 2. Genetic relatedness between races of Fusarium oxysporum f. sp. lycopersici

\begin{tabular}{|c|c|c|c|c|c|c|}
\hline $\begin{array}{l}\text { Race of } \mathrm{f} . \mathrm{sp} . \\
\text { lycopersici }\end{array}$ & $\begin{array}{c}\text { race J1 } \\
\text { (SUF 119) }\end{array}$ & $\begin{array}{c}\text { race } 1 \\
\text { (AFL 626) }\end{array}$ & $\begin{array}{c}\text { race J2 } \\
\text { (SUF 803) }\end{array}$ & $\begin{array}{c}\text { race } 2 \\
\text { (AFL 548) }\end{array}$ & $\begin{array}{c}\text { race } \mathrm{J} 3 \\
\text { (FOly) }\end{array}$ & $\begin{array}{c}\text { race } 3 \\
\text { (AFL 5397) }\end{array}$ \\
\hline \multicolumn{7}{|l|}{ race $\mathbf{J} 1$} \\
\hline Tomato V & 98.3 a) & 96.7 & 97.9 & 98.2 & 84.2 & 97.9 \\
\hline $\begin{array}{l}\text { Tomato } \mathrm{H} \\
\text { race } 1\end{array}$ & 96.1 & N.D. b) & 98.3 & N.D. & 79.3 & 98.9 \\
\hline AFL 7388 & 97.6 & 98.2 & 98.7 & 98.9 & 86.8 & 99.1 \\
\hline \multicolumn{7}{|l|}{$\operatorname{race} \mathbf{J} 2$} \\
\hline IFO 31213 & 99.1 & 96.8 & 98.2 & 97.3 & 88.2 & 97.8 \\
\hline F-1 & 97.9 & 98.2 & 98.9 & 99.1 & 82.9 & 98.6 \\
\hline $\begin{array}{r}F-8 \\
\text { race } 2\end{array}$ & N.D. & 98.7 & N.D. & N.D. & 79.4 & N.D. \\
\hline $\begin{array}{l}\text { AFL } 7399 \\
\text { race J3 }\end{array}$ & 98.2 & N.D. & 99.3 & N.D. & 74.9 & 99.0 \\
\hline Mie & 86.3 & 81.9 & 78.9 & 76.2 & 98.7 & 76.9 \\
\hline KEF-2R1 & 84.7 & 82.6 & 79.5 & 80.1 & 99.2 & 78.3 \\
\hline $\begin{array}{l}\text { F212 } \\
\text { race } 3\end{array}$ & 86.3 & 88.9 & 74.4 & 81.6 & 99.3 & 79.9 \\
\hline AFL 8174 & 99.3 & N.D. & 98.4 & N.D. & 79.3 & 98.8 \\
\hline
\end{tabular}

a) Homology values $(\%)$ are average of two determinations, and were calculated from the equation described by Seidler and Mandel $^{33}$.

b) Not determined.

Table 3. Genetic relatedness between race of Fusarium oxysporum $\mathrm{f}$. sp. lycopersici and other formae speciales of Fusarium oxysporum

\begin{tabular}{|c|c|c|c|}
\hline $\begin{array}{l}\text { Forma } \\
\text { specialis }\end{array}$ & $\begin{array}{c}\text { race J1 } \\
\text { (SUF 119) }\end{array}$ & $\begin{array}{l}\text { lycopersici } \\
\text { race J2 } \\
\text { (SUF 803) }\end{array}$ & $\begin{array}{r}\text { race J3 } \\
\text { (FOly) }\end{array}$ \\
\hline $\begin{array}{l}\text { radicis-lycopersici } \\
\quad(\mathrm{CC} \# 85)\end{array}$ & $86.3-88.2$ a) & $78.2-85.3$ & $97.7-99.8$ \\
\hline $\begin{array}{l}\text { melongenae } \\
\text { (IFO 9963) }\end{array}$ & $80.3-82.8$ & 79. $2-84.1$ & $81.8-87.4$ \\
\hline $\begin{array}{l}\text { nicotianae } \\
\quad \text { (IFO 6386) }\end{array}$ & $84.7-86.0$ & $80.4-83.6$ & $82.8-86.2$ \\
\hline $\begin{array}{l}\text { melonis } \\
\quad \text { (F.O.-1) }\end{array}$ & $68.4-70.4$ & $73.8-76.2$ & $71.8-73.1$ \\
\hline $\begin{array}{l}\text { raphani } \\
\quad(\mathrm{R} 772121)\end{array}$ & $73.5-76.9$ & $68.1-70.0$ & $71.9-75.2$ \\
\hline $\begin{array}{l}\text { phaseoli } \\
\quad \text { (IFO 9970) }\end{array}$ & $76.6-80.1$ & $72.8-75.6$ & $75.7-80.3$ \\
\hline $\begin{array}{l}\text { gladioli } \\
\quad \text { (IFO 7166) }\end{array}$ & $75.6-77.6$ & $71.8-73.8$ & $69.2-72.2$ \\
\hline $\begin{array}{l}\text { asparagi } \\
\quad \text { (IFO 31382) }\end{array}$ & $73.1-75.5$ & $78.5-80.4$ & $72.2-76.9$ \\
\hline $\begin{array}{l}\text { spinaciae } \\
\text { (F 58) }\end{array}$ & $68.4-70.8$ & $70.3-74.0$ & 74. $1-76.3$ \\
\hline
\end{tabular}

a) The range of homology values $(\%)$ is the results of two determinations and was calculated from the equation described by Seidler and $\mathrm{Mandel}^{33)}$.

lycopersici was further determined. All the isolates of race $\mathrm{J} 3$ examined hybridized at consistently high rates $(95.3-100 \%)$ with isolate CC\#85 of forma specialis radicis-lycopersici, as shown in Table 4. 
Table 4. Genetic relatedness between race $\mathrm{J} 3$ of Fusarium oxysporum f. sp. lycopersici and Fusarium oxysporum f. sp. radicis-lycopersici

\begin{tabular}{lc}
\hline $\begin{array}{c}\text { Race J3 of f. sp. } \\
\text { lycopersici }\end{array}$ & $\begin{array}{c}\text { f. sp. radicis-lycopersici } \\
\text { (CC\#85) }\end{array}$ \\
\hline Mie & $96.8-99.6$ a) \\
KEF-2R1 & $98.9-100$ \\
KEF-2R4 & $97.3-98.1$ \\
F212 & $98.3-99.7$ \\
F213 & $96.1-98.7$ \\
Y31 & $96.3-97.8$ \\
Y11a & $98.3-99.0$ \\
\hline
\end{tabular}

a) See footnote in Table 3 .

Table 5. Relationships between DNA homology and subspecific taxa of Fusarium oxysporum

\begin{tabular}{cl}
\hline \hline $\begin{array}{c}\text { Spectroscopic method of } \\
\text { Kuninaga } \text { et al. }(1989)^{20)} \\
(\% \text { homology })\end{array}$ & Taxonomic statement \\
\hline $95-100$ & The same forma specialis or a race within the same forma specialis \\
$85-94$ & Closely related but different forma specialis \\
$60-84$ & Different forma specialis \\
$0-59$ & Different species \\
\hline
\end{tabular}

\section{DISCUSSION}

Although most pathogenic forms of Fusarium oxysporum show a high degree of host specificity, some forms are pathogenic to a wide range of host plants either of the same family ${ }^{1,3}$ ) or across many families ${ }^{2,4}$. Identifying formae speciales and physiological races of this species solely from pathogenicity tests, therefore, is difficult and often inconclusive. Disagreement on classification exists in the literature as to whether strains of $F$. oxysporum causing tomato crown and root rot disease be categorized as a new forma specialis ${ }^{14,29)}$ or as a physiological race within forma specialis lycopersici ${ }^{22,31,32,38)}$.

We showed in a previous paper ${ }^{20}$ ) that the DNA reassociation technique used in this study provided a reliable criterion to delimit subspecific taxa in $F$. oxysporum. In Table 5, we suggest how DNA homology values obtained with the method should be interpreted.

The present investigations revealed that the Japanese race $\mathrm{J} 3$ of $F$. oxysporum $\mathrm{f}$. $\mathrm{sp}$. lycopersici share only 74-88\% DNA homology with other races, including American races, of this forma specialis. Judging from the criteria shown in Table 5, it is suggested that the causal fungus of tomato crown and root rot should be classified into a single forma specialis distinct from forma specialis lycopersici.

The data presented here demonstrated further that all the tomato crown and root rot pathogens examined are genetically identical with strain of $F$. oxysporum f. sp. radicis-lycopersici and are distinct from other formae speciales in this species. These results coincide with current views $^{9,28)}$ that tomato crown and root rot isolates has been assigned to its own single-member vegetative compatibility group in Puhalla's ${ }^{28)}$ classification of strains of $F$. oxysporum.

Symptoms of Fusarium crown and root rot disease are quite unlike those caused by races of $F$. oxysporum f. sp. lycopersici ${ }^{13,27,29,32,35,38)}$. The disease is also favored by cool soil temperature, in contrast to races of forma specialis lycopersici $i^{13,32,38)}$. In view of these differences, Jarvis and Shoemaker ${ }^{12,14}$ have proposed that Fusarium crown and root rot pathogen be designated new forma specialis radicis-lycopersici, based on its mode of pathogenesis, its tempera- 
ture relations, and its close association with Lycopersicon spp. Rowe ${ }^{29)}$ has supported Jarvis and Shoemaker's designation despite his observations that tomato crown and root rot isolates are pathogenic, on inoculation, to host plants outside the Solanaceae. Our results presented here certainly demonstrate the validity of subspecific classification of this pathogen as a new single forma specialis to distinguish it from the organisms causing typical Fusarium wilt. Accordingly, we propose that tomato crown and root rot isolates found in Japan should be referred to as $F$. oxysporum $\mathrm{f}$. sp. radicis-lycopersici.

It is recently reported that two formae speciales, radicis-lycopersici and lycopersici are quite different with respect to protein composition ${ }^{5)}$, antibiotic tolerance ${ }^{23)}$ and complement of fatty $\operatorname{acids}^{23)}$.

The present study indicated that tomato crown and root rot isolate (FOly) showed comparatively high homology in DNA sequence with strains of formae speciales lycopersici, melongenae and nicotianae pathogenic to host plants from the Solanaceae. In a previous paper ${ }^{20)}$, similar results were also observed between Fusarium strains from the Cruciferae or the Cucurbitaceae. These results suggest that formae speciales in $F$. oxysporum parasitizing host plants within the same botanical family may show phylogenetically close relationships with each other.

Japanese races in $F$. oxysporum $\mathrm{f}$. sp. lycopersici are described by the designation of $\mathrm{J} 1$ or J2, distinct from that in U.S.A., because a set of tomato differential cultivars or lines used for identification of races is different in both countries. Since race $\mathbf{J} 2$ was found to be pathogenic to tomato cultivars having the Lycopersicon pimpinellifolium Accession 160 factor (I-factor) for resistance to race $\mathrm{J} \mathbf{1}^{36}$, it seems that races $\mathrm{J} 1$ and $\mathrm{J} 2$ correspond to races 1 and 2 , respectively. A correlation between these races from both countries is not, however, examined closely. This study showed these races, including new race 3 recently reported, to be closely homogeneous. It is reported that each of races (1 and 2$)$ can be distinguished serologically ${ }^{26)}$. Further investigations must be undertaken to explore alternative or complementary methods to expedite race classification of this forma specialis.

The authors wish to thank Dr. W.R. Jarvis, Agriculture Canada Research Station for critically reviewing the manuscript and for providing the isolate, and also Mr. H. Hagiwara, National Agriculture Research Center, Mr. N. Kita, Kanagawa Horticulture Experiment Station for useful suggestion and providing the isolates. Thanks are also due to Mr. T. Kobayashi, Kochi Pref. Institute of Agricultural Forest Science, and Dr. J.P. Jones, University of Florida, for their kind supply of the isolates.

\section{Literature cited}

1. Armstrong, G.M. and Armstrong, J.K. (1966). Races of Fusarium oxysporum f. conglutinans; race 4, new races; and a new host for race 1, Lychnis chalcedonica. Phytopathology 56: 525-530.

2. Armstrong, G.M. and Armstrong, J.K. (1969). Relationships of Fusarium oxysporum formae speciales apii, asparagi, cassiae, melongenae, and vasinfectum race 3 as revealed by pathogenicity for common hosts. Phytopathology 59: 1256-1260.

3. Armstrong, G.M. and Armstrong, J.K. (1978). Formae speciales and races of Fusarium oxysporum causing wilts of the Cucurbitaceae. Phytopathology 68: 19-28.

4. Armstrong, G.M. and Armstrong, J.K. (1978). A new race (race 6) of the cotton wilt Fusarium from Brazil. Plant Dis. Reptr. 62: 421-423.

5. Belhadj, R., Charest, P.-M. and Theriault, G. (1987). Electrophoretic comparison of the protein composition of two closely related fungi: Fusarium oxysporum $\mathrm{f}$. sp. radicis-lycopersici (FORL) and F. oxysporum f. sp. lycopersici (FOL). Can. J. Plant Pathol. 9: 272-273 (Abstr.).

6. Benhamou, N., Charest, P.-M. and Jarvis, W.R. (1989). Biology and host-parasite relations of Fusarium oxysporum f. sp. radicis-lycopersici. In Vascular Wilt Disease of Plants (Tjamos, E.C. and Beckman, C. eds.). Springer-Verlag, Berlin, Heidelberg. pp. 95-105.

7. Britten, R.J., Pavich, M. and Smith, J. (1969). A new method for DNA purification. Carnegie Instn. Year Book 68:400-402. 
8. Coddington, A., Matthews, P.M., Cullis, C. and Smith, K.H. (1987). Restriction digest patterns of total DNA from different races of Fusarium oxysporum f. sp. pisi - an improved method for race classification. J. Phytopath. 118: 9-20.

9. Correll, J.C., Klittich, C.J.R. and Lesilie, J.F. (1987). Nitrate nonutilizing of Fusarium oxysporum and their use in vegetative compatibility tests. Phytopathology 77: 1640-1646.

10. Gabe, H.L. (1975). Standardization of nomenclature for pathogenic races of Fusarium oxysporum f. sp. lycopersici. Trans. Br. mycol. Soc. 64:156-159.

11. Grattidge, R. and O'Brien, R.G. (1982). Occurrence of a third race of Fusarium wilt of tomatoes in Queensland. Plant Dis. 66: 165-166.

12. Jarvis, W.R. (1988). Fusarium crown and root rot of tomatoes. Phytoprotection 69: 49-64.

13. Jarvis, W.R., Thorpe, H.J. and Macneill, B.H. (1975). A foot and root rot disease of tomato caused by Fusarium oxysporum. Can. Plant Dis. Surv. 55: 25-26.

14. Jarvis, W.R. and Shoemaker, R.A. (1978). Taxonomic status of Fusarium oxysporum causing foot and root rot of tomato. Phytopathology 68: 1679-1680.

15. Kistler, H.C., Bosland, P.W., Benny, U., Leong, S. and Williams, P.H. (1987). Relatedness of strains of Fusarium oxysporum from crucifers measured by examination of mitochondrial and ribosomal DNA. Phytopathology 77: 1289-1293.

16. Kita, N., Ushiyama, K. and Aono, N. (1988). Crown and root rot of tomatoes in Kanagawa. Bull. Kanagawa Horticultural Exp. Sta. 35: 1-6.

17. Komada, H. (1980). Fusarium wilt of tomato (crown and root rot). In Fusarium Disease of Cultivated Plants (Matuo, T., Komada, H. and Matsuda, A. eds.). Zenkoku Noson Kyoiku Kyokai Publishing Co., Ltd., Tokyo. p. 437.

18. Krikun, J.A., Nachmias, A., Cohn, R. and Lahkim-Tsror, L. (1982). The occurrence of Fusarium crown and root rot of tomato in Israel. Phytoparasitica 10: 113-115.

19. Kuninaga, S. and Yokosawa, R. (1982). DNA base sequence homology in Rhizoctonia solani Kühn. I. Genetic relatedness within anastomosis group 1. Ann. Phytopath. Soc. Japan 48: 659-667.

20. Kuninaga, S. and Yokosawa, R. (1989). Genetic relatedness within and between formae speciales of Fusarium oxysporum as measured by DNA-DNA reassociation kinetics. Ann. Phytopath. Soc. Japan 55: 216-223.

21. Kuninaga, S. and Yokosawa, R. (1989). Studies on taxonomy of phytopathogenic fungi by comparison of DNA homology: III. Genetic relatedness among races in Fusarium oxysporum f. sp. lycopersici. Ann. Phytopath. Soc. Japan 55: 485 (Abstr.).

22. Leary, J.V. and Endo, R.M. (1971). A Fusarium-induced root rot of staked tomatoes. Phytopathology 61: 900 (Abstr.).

23. Madosingh, C. and Starratt, A.N. (1987). Comparison of antibiotic tolerance, lipids and respiration in the tomato pathogens Fusarium oxysporum f. sp. lycopersici and $F$. oxysporum f. sp. radicislycopersici. J. Environ. Sci. Health B22: 731-749.

24. Malathrakis, N.E. (1985). Tomato crown and root rot caused by Fusarium oxysporum f. sp. radicislycopersici in Greece. Plant Pathol. 34: 438-439.

25. Manicom, B.Q., Bar-Joseph, M., Rosner, A., Vigodsky-Haas, H. and Kotze, J.M. (1987). Potential applications of random DNA probes and restriction fragment length polymorphisms in the taxonomy of the Fusaria. Phytopathology 77: 669-672.

26. Morton, D.J. and Dukes, P.D. (1966). Serological differentiation of race 1 from race 2 of Fusarium oxysporum f. sp. lycopersici. Plant Dis. Reptr. 50: 444-445.

27. Nutter, F.W., Jr., Warren, C.G., Wells, O.S. and MacHardy, W.E. (1978). Fusarium foot and root rot of tomato in New Hampshire. Plant Dis. Reptr. 62: 976-978.

28. Puhalla, J.E. (1985). Classification of strains of Fusarium oxysporum on the basis of vegetative compatibility. Can. J. Bot. 63: 179-183.

29. Rowe, R. (1980). Comparative pathogenicity and host ranges of Fusarium oxysporum isolates causing crown and root rot of greenhouse and field-grown tomatoes in North America and Japan. Phytopathology 70: 1143-1148.

30. Rowe, R.C., Farley, J.D. and Coplin, D.L. (1977). Air-borne spore dispersal and recolonization of steamed soil by Fusarium oxysporum in tomato greenhouses. Phytopathology 67: 1513-1517.

31. Sanchez, L.E., Endo, R.M. and Leary, J.V. (1975). A rapid technique for identifying the clones of Fusarium oxysporum f. sp. lycopersici causing crown and root rot of tomato. Phytopathology 65: 726-727. 
32. Sato, R. and Araki, T. (1974). On the tomato root rot disease occurring under vinyl-house condition in southern Hokkaido. Rep. Soc. Plant Prot. North Japan 25: 5-13.

33. Seidler, R. and Mandel, M. (1971). Quantitative aspects of deoxyribonucleic acid renaturation: base composition, state of chromosome replication, and polynucleotide homologies. J. Bacteriol. 106: 608-614.

34. Seidler, R., Knittel, M.D. and Brown, C. (1975). Potential pathogens in the environment: cultural reactions and nucleic acid studies on Klebsiella pneumoniae from clinical and environmental sources. Appl. Microbiol. 29: 819--825.

35. Sonoda, R.M. (1976). The occurrence of a Fusarium root rot of tomatoes in south Florida. Plant Dis. Reptr. 60: 271-274.

36. Sugawara, Y. and Suzuki, I. (1966). Studies on pathogenicity of Fusarium wilt fungus in vegetable crops. I. An isolates of Fusarium oxysporum f. sp. lycopersici having different pathogenicity from common race in Japan. Bull. Hort. Exp. Sta. B.5: 1-28.

37. Volin, R.B. and Jones, J.P. (1982). A new race of Fusarium wilt of tomato in Florida and sources of resistance. Proc. Fla. State Hort. Soc. 95: 268-270.

38. Yamamoto, I., Komada, H., Kuniyasu, K., Saito, M. and Ezuka, A. (1974). A new race of Fusarium oxysporum f. sp. lycopersici inducing root rot of tomato. Proc. Kansai Plant Prot. Soc. 16: 17-29.

\section{和 文 摘 要}

国永史朗・横沢菱三：DNA-DNA 再会合反応速度解析によるトマト根腐れ萎らょう病菌の分類的位置の 検討

トマト根腐れ萎ちょら病の病原菌は，わが国では Fusarium oxysporum f. sp. lycopersici の race J3 とされ てきたが，諸外国では，別の分化型である radicis-lycopersici に分類されている。この分類学的な不一致を 解決する目的で，DNA-DNA 再会合反応速度解析法を用いて，f. sp. lycopersici と f. sp. radicis-lycopersici 間の遺伝的関係を検討した。その結果, f. sp. lycopersici race $\mathrm{J} 3$ の菌株は本分化型の他のレ一ス $(\mathrm{J} 1, \mathrm{~J} 2,1$, 2,3) の菌株とは明らかに遺伝的に異なり（74～88\% の DNA 相同性）, f. sp. radicis-lycopersici の菌株と遺 伝的に一致する（96 99\% の DNA 相同性）ことが確認された。以上のことから，わが国においてもトマ ト根腐れ萎らょら病の病原菌は Fusarium oxysporum f. sp. radicis-lycopersici とすべさであると考兄られた 